\title{
REVIEWS.
}

\section{AN INTRODUCTION TO PRACTICAL BACTERIOLOGY.}

\author{
By T. J. Mackie and J. E. McCartney. \\ 4th Edition, $1934 . \quad 504$ pp. \\ Published by E. and S. Livingstone, \\ Edinburgh. Price 12/6.
}

The subject of bacteriology has now become so complex that it is hardly possible for a survey to be given within the compass of a relatively small textbook.

The present authors have intended their book to serve as a guide to bacteriological laboratory work and for this reason information on general problems and immunity is scanty. This, though unavoidable, detracts from the interest of the work. Illustrations of micro-organisms and cultures have been omitted because the book is intended for use in the laboratory, where actual preparations are available. At the same time it cannot be denied that illustrations are particularly valuable as a guide to the inexperienced who may be examining slides of malarial parasites, intestinal amœbæ, preparations from the mycoses, etc.

It is also felt that the importance of the Sonne Bacillus justifies its promotion from small to large type, and further that too much is made of the difficulty of finding tubercle bacilli in the urine and cerebrospinal fluid. In the latter material we are told to seek the bacilli in the centrifuged deposit, although they are more often found in the clot.

These are minor points of criticism however, and for the rest, it may be said that the details of laboratory technique (Widal, Wassermann, etc.) are clear and practical, and accounts of the individual bacteria are adequate and concise. Indeed, within the limitations imposed by its authors, this textbook is completely successful and should prove of great service as a handbook for students, as a guide to technique and as a small and convenient work of reference in the laboratory.

\section{ADVICE TO THE EXPECTANT MOTHER ON THE CARE OF HER HEALTH.}

By F. J. Browne, M.D., F.R.C.S., F.C.o.G.

Published by E. and S. Livingstone, Edinburgh. 48 pp. Frice 6 d.

All those who practice Medicine and who are asked from time to time by Expectant Mothers for the name of a book to read which will help them to prepare for the coming confinement, can recommend Professor Browne's little book. This, the third edition, has been brought up to date. As the author states the book has been written to supplement, and not to take the place of, personal interviews with the physician.

The chapters on Normal Pregnancy and the Common Disorders of Pregnancy are excellent. The preparations for the confinement are more than adequate and as suggested could be fulfilled by only a small proportion of the population. The work concludes with some Hints on Breast Feeding. Were adverse criticism possible, it could only be directed to Chapter 1 which sets out in perhaps too optimistic a manner the benefits that may be expected of Ante-Natal Care. The advice given throughout is eminently sound, the printing is clear, and the whole work is admirable. 